\title{
Does pea lectin expressed transgenically in oilseed rape (Brassica napus) influence honey bee (Apis mellifera) larvae?
}

\author{
Anna LEHRMAN* \\ Department of Ecology, Swedish University of Agricultural Sciences, P.O. Box 7044, SE-750 07 Uppsala, Sweden
}

\begin{abstract}
The European honey bee (Apis mellifera) is important both for pollination and for honey production. Pollen is the major protein source for bees, which exposes them directly to changes in pollen quality e.g. through genetic engineering. In order to create a worst case scenario regarding pea lectin (PSL) expressed transgenically in oilseed rape anthers and pollen, the maximum amount of dried pollen that could be mixed in an artificial diet without negatively affecting larval performance $(1.5 \% \mathrm{w} / \mathrm{w})$ was fed to bee larvae. Pollen from two transgenic plant lines expressing PSL up to $1.2 \%$ of total soluble protein and pollen from one non-transgenic line was added to the same diet and used as a pollen control. When these three pollen diets and the control diet (without added pollen) were compared, no negative effect from the pollen of the transgenic plants could be detected on larval mortality, weight, or development time. An increased weight and a reduced developmental time were recorded for larvae on all diets containing pollen when compared to the diet without pollen.
\end{abstract}

Keywords: lectin / PSL / transgenic oilseed rape / honey bee larvae

\section{INTRODUCTION}

Part of the risk assessment of transgenic crops is the evaluation of possible negative effects on non-target organisms. The organisms selected for testing will depend on factors such as abundance in the field, ease of handling in the laboratory, taxonomic certainty, value to the agroecosystem, and endangered status (O'Callaghan et al., 2005). The European honey bee (Apis mellifera (L.)) is one of the most important pollinators in agriculture. Many crops are more or less dependent on insect pollination (Klein et al., 2007), and with declining wild bee populations, growers will depend even more on pollination services from honey bees. Thus, the honey bee is considered a key species for risk assessments of transgenic crop varieties before their introduction in the field.

Pollen is the main protein source for bees (Crailsheim, 1990; Crailsheim et al., 1992), and it also provides lipids, vitamins, minerals, starch, and some sugars (Winston, 1987). Nectar contains relatively low levels of protein (Baker and Baker, 1986), and therefore it is mainly through pollen that honey bees might come into contact with transgenic products, if the transgene is expressed in the pollen. In the plant material used in the present study, the expression of the foreign protein (pea lectin) was restricted to the pollen (Melander et al.,

* Corresponding author: anna.lehrman@entom.slu.se
2003), in order to target the pollen beetle (Meligethes aeneus (L.)), which also uses the pollen as a protein source.

The pollen beetle is a severe pest in oilseed rape crops where it may cause up to $70 \%$ yield loss (Nilsson, 1987). The beetle lays its eggs in the buds, but more severely, it damages buds while feeding, leaving pod-less stalks. The common control solution in northern Europe has been to spray with pyrethroids. However, problems with insecticide-resistant pollen beetles have occurred in several countries (Derron et al., 2004; Ekbom and Kuusk, 2001; Hansen, 2003), and as a consequence, insecticides that have been prohibited are now allowed again in some areas (Andersson et al., 2006).

Lectins, or agglutinins, are proteins that bind reversibly to specific carbohydrates, which in plants are suggested to function both as storage proteins and defence against herbivores and pathogens (Gatehouse and Gatehouse, 1996; Murdock and Shade, 2002; Peumans and Van Damme, 1995). The effect of different lectins is highly specific for each lectin and insect combination even within the same insect order (Sétamou et al., 2002), and the mechanisms of action determining the level of toxicity also seem to vary (Harper et al., 1995; Murdock and Shade, 2002). In insects, lectins can disturb nutrition uptake (Eisemann et al., 1994), disrupt the midgut peritrophic membrane (Harper et al., 1998) and epithelial barrier (Powell et al., 1998), leading to 
negative impact on insect performance. In a screening for potential resistance factors against the pollen beetle, pea (Pisum sativum) lectin (PSL) was selected, and the corresponding gene was transformed into oilseed rape (Brassica napus) (Åhman and Melander, 2003; Melander et al., 2003). Feeding on anthers from this plant material reduced pollen beetle larval weight (Melander et al., 2003) but had no effect on adult beetles (Lehrman et al., 2007). PSL has also been shown to reduce the survival rates of other insects, for example the American bollworm (Helicoverpa armigera) (Gupta et al., 2005) and the alfalfa weevil (Hypera postica) (Elden, 2000).

Large quantities of pollen are collected by adults bees to provide the larvae with food, but also for their own consumption (Crailsheim et al., 1992; Haydak, 1963). The young honey bee larvae (up to 3.5 days old) are fed with royal jelly produced in the hypopharyngeal glands of nursing bees (Crailsheim, 1990) and is almost completely without pollen (Planta, 1988 in: Haydak, 1943). During subsequent development the composition of the food is altered depending on the caste. For workers or drones the diet contains more pollen and honey but less royal jelly than if a queen is being raised (Winston, 1987). Proteins that are present in the hypopharyngeal glands might be transferred to the larvae through the royal jelly provided by the nursing bees (Brødsgaard et al., 2003), but so far there is no evidence that ingested proteins accumulate and can be transferred intact via the hypopharyngeal glands (Malone et al., 2004). Many lectins, however, are stable proteins; insensitive to $\mathrm{pH}$, high temperatures, and resistant to animal proteases (Peumans and Van Damme, 1995). Snowdrop lectin (GNA) has been detected in the ovarioles, fat bodies, and haemolymph of the Rice brown planthoppers (Nilaparvata lugens) when fed a diet containing GNA (Powell et al., 1998). This may be important when considering the risk of bee larvae receiving transgenic lectin through the brood food.

Several studies present the effects of transgenic insect resistance products on honey bees, e.g. proteinase inhibitors (PIs) (Brødsgaard et al., 2003; Burgess et al., 1996; Sagili et al., 2005), Bacillus thuringiensis (Bt) toxins (Arpaia, 1996; Malone et al., 2004) and biotinbinding proteins (Malone et al., 2002). Some have been conducted using transgenic plant material on adults (Babendreier et al., 2005; Liu et al., 2005), but few have considered the effects of transgenic plants on honey bee larval stages (Hanley et al., 2003). Larvae, undergoing growth, might be more sensitive to changes in food composition than adults. The protective perithrophic membrane within the midgut starts to develop almost immediately after hatching of the larvae. However, it does not reach full thickness and cover until day three (Davidson, 1970), which might render the young larvae more vulnerable to toxins in their food. So far, the only published studies considering the effects of lectin on honey bees have been conducted using adult bees. No negative effects were found when the bees foraged on leek ( $A l$ lium porrum (L.)) (Peumans et al., 1997) where the $A l$ lium lectin occurs naturally in the nectar, neither was any increased mortality recorded when adult bees were feed a diet containing wheat germ agglutinin (WGA) (Belzunces et al., 1994).

The present study is part of a risk/benefit analysis, concerning the effects of oilseed rape engineered for resistance against the pollen beetle. Here the impact of pea lectin on honey bee larval survival, development, and weight is investigated. Under natural conditions honey bee larvae do not receive pollen in their food during the first days after egg hatch. I have, however, chosen to feed pollen to young larvae because I wished to create a worstcase scenario in order to test the potential hazard that transgenic oilseed rape expressing PSL in the anthers and pollen could pose to honey bee larvae.

\section{RESULTS}

\section{Pollen analyses}

The sieved fresh pollen samples contained on average $11162( \pm 506, \mathrm{n}=3)$ pollen grains. $\mathrm{mg}^{-1}$ and lost $62 \%$ $( \pm 0.8)$ of their weight when dried. Therefore a diet of $1.5 \%$ dry pollen corresponds to $4 \%( \pm 0.15)$ of fresh pollen in the larval food (w/w).

The protein content ranged from 6.7 to $8.6 \%(\mathrm{w} / \mathrm{w})$ (Tab. 1), with the highest protein concentration in C-112. Two bands corresponding to a molecular size of $17 \mathrm{kD}$ and $26 \mathrm{kD}$ could be observed in the transgenic pollen (Fig. 1), whereas no such bands could be seen in the control line. The larger band corresponds to pro-lectin, the uncleaved PSL. This protein has the same sugar binding activity as the cleaved protein (Prasthofer et al., 1989). Thus, the sum of the two bands was used when calculating the amount of PSL. The percentage PSL of total soluble protein was slightly higher in T-17 but the lower concentration of total protein in this line resulted in similar quantities of PSL in the diets based on the two transgenic plant lines T-17 and T-132 (Tab. 1).

\section{Feeding assay 1; pollen concentration}

There was a significant difference in the mean numbers of surviving larvae on day 5 among those fed with pollen at different concentrations $\left(\mathrm{F}_{4,14}=9.42, \mathrm{p}=0.002\right)$. Least squares means for effect of pollen concentration showed no significant difference between 0 and $1 \%$ pollen (w/w) but the difference between 0 and $2 \%$ was significant ( $\mathrm{p}<0.05$, at day 5) (Fig. 2). Based on these results, a level 
Table 1. Percentage of total soluble protein in the dried pollen, percentage PSL of total soluble protein and PSL in the different diets ( \pm s.e., $\mathrm{n}=3$ per plant line).

\begin{tabular}{lccc}
\hline \hline Plant line & Total soluble protein $(\%)$ & PSL of total soluble protein $(\%)$ & PSL in diet $(\%)$ \\
\hline T-17 & $6.7( \pm 0.4)$ & $1.2( \pm 0.2)$ & 0.0012 \\
T-132 & $7.7( \pm 0.3)$ & $1.1( \pm 0.0)$ & 0.0012 \\
C-112 & $8.6( \pm 0.5)$ & 0 & 0 \\
\hline
\end{tabular}

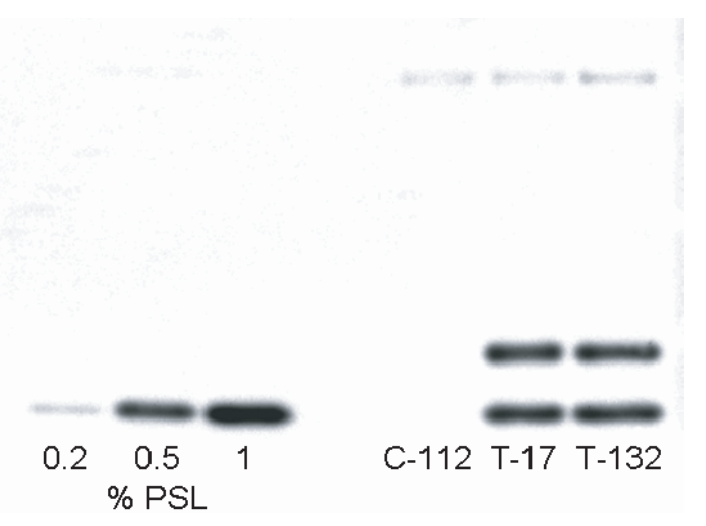

Figure 1. Western blot of PSL in dried pollen from three plant lines. For comparison, the first three lanes contain purified PSL in the cleaved form; $5,12.5$ and $25 \mathrm{ng}$, corresponding to $0.2,0.5$ and $1 \%$ PSL in the samples. The following lanes each contain $2.5 \mu \mathrm{g}$ of soluble protein from pollen of a control line; C-112 and two transgenic lines; T-17, T-132. Band sizes 26 and $17 \mathrm{kD}$.

of $1.5 \%$ pollen was chosen for the lectin experiments, which equals an average of 172 pollen grains. $\mathrm{mg}^{-1}$ food in this experiment.

\section{Feeding assay 2; transgenic pollen}

Repeated measures analysis showed a significant difference in the proportion of survivors among diets $\left(\mathrm{F}_{3,216}=\right.$ 17.11, $\mathrm{p}<0.0001$, Fig. 3a). The control diet without pollen and the diet with T-132 pollen had a significantly higher number of survivors compared to those fed on the diets with T-17 and C-112 pollen at day six (Fig. 3a). The same pattern was seen at the LS-stage (larvae becomes passive and starts to excrete faeces (Rembold et al., 1980)) (Fig. 3b), but no significant differences were found among diets in the pupal stage $\left(\mathrm{F}_{4,39}=0.17, \mathrm{p}=\right.$ 0.92).

\section{Larval weight}

There were significant differences in larval weight among the bees fed the four diets $\left(\chi^{2}=30.71\right.$, d.f. $=3, \mathrm{p}<$

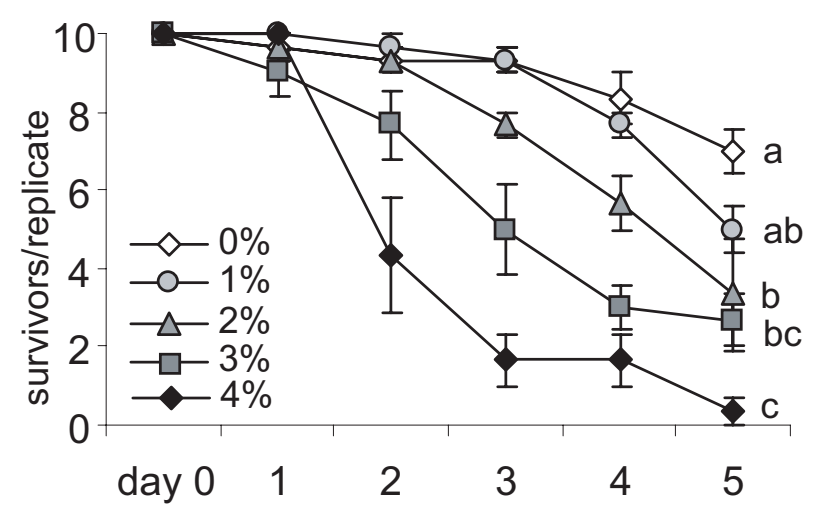

Figure 2. Mean number ( \pm s.e.) of surviving larvae per replicate, when feeding on different concentrations of nontransgenic pollen. Different letters indicate significant differences in survival at day $5(\mathrm{p}<0.05)$.

0.0001). The larvae on the control diet had significantly lower weights compared to all of those fed with pollen diets (Fig. 4). To ascertain if there were any differences among the three different pollen-containing diets a new test was performed excluding the control diet, but no significant difference in larval weight among the three pollen diets was found $\left(\chi^{2}=0.30\right.$, d.f. $\left.=2, p=0.86\right)$.

\section{Developmental time}

There was a significant difference among diets in developmental time until the LS-stage when considering all treatments together $\left(\chi^{2}=46.20\right.$, d.f. $\left.=3, p<0001\right)$, but no differences among the three pollen diets in this respect $\left(\chi^{2}=4.48\right.$, d.f. $\left.=2, p=0.11\right)$ (Fig. 5). The pattern was the same for development time from LS to the pupal stage; significant differences among treatments when considering all tests $\left(\chi^{2}=31.75\right.$, d.f. $\left.=3, p<0001\right)$, but no difference among the three different pollen diets $\left(\chi^{2}=2.30\right.$, d.f. $=2, p=0.32$ ).

A significant negative correlation between weight at the LS stage and development time to that same stage was found $\left(\mathrm{r}_{\mathrm{s}}=-0.52, \mathrm{n}=280, \mathrm{p}<0.0001\right)$. However, the correlation coefficient was lower for larval weight and 


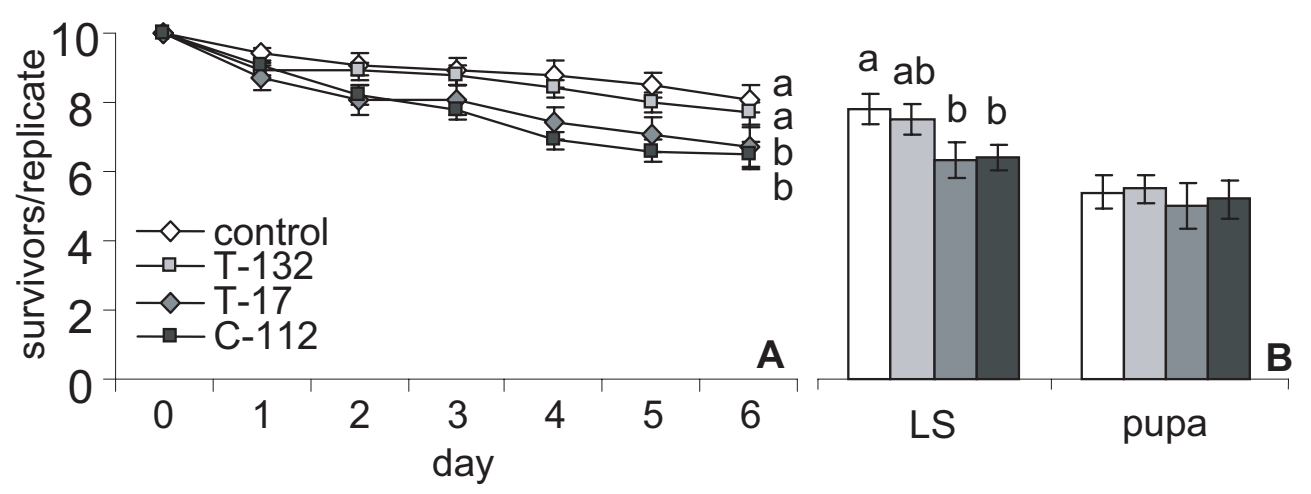

Figure 3. Mean number of surviving larvae ( \pm s.e.), per replicate, until day six (A) LS, and pupal stage (B). Different letters indicate significant differences in survival rates by repeated measures (A) and least squares means test for differences $(B)(p<0.05)$.

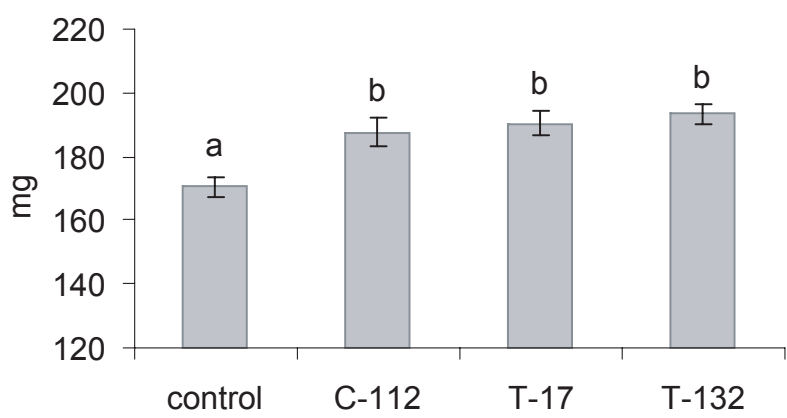

Figure 4. Mean larval weights at the LS-stage after feeding on the four different diets. Weights of bee larvae on the control diet were significantly lower than those of larvae on pollen containing diets (Kruskal-Wallis $\chi^{2}=30.32$, d.f. $=1, \mathrm{p}<0.0001$ ).

development time to the pupal stage $\left(\mathrm{r}_{\mathrm{s}}=-0.34, \mathrm{n}=211\right.$, $\mathrm{p}<0.0001)$.

\section{DISCUSSION}

This novel study on the influence of pea lectin on honey bee larvae found no effect on survival to pupation when larvae were fed a diet containing $1.5 \%$ dried oilseed rape pollen, expressing the foreign protein up to $1.2 \%$ (of total soluble protein in the pollen) which is $0.0012 \%$ pea lectin in the diet $(\mathrm{w} / \mathrm{w})$. The only differences in survival between diets were found during the larval and LSstages. The differences detected were not, however, between transgenic and non-transgenic diets. No differences among diets were discernable when the bees pupated. Larval weight was lower and development time was longer for larvae not receiving pollen in the diet. There was, however, no difference in weight or development time between diets with transgenic and non-transgenic pollen. This suggests that the transgene product pea lectin

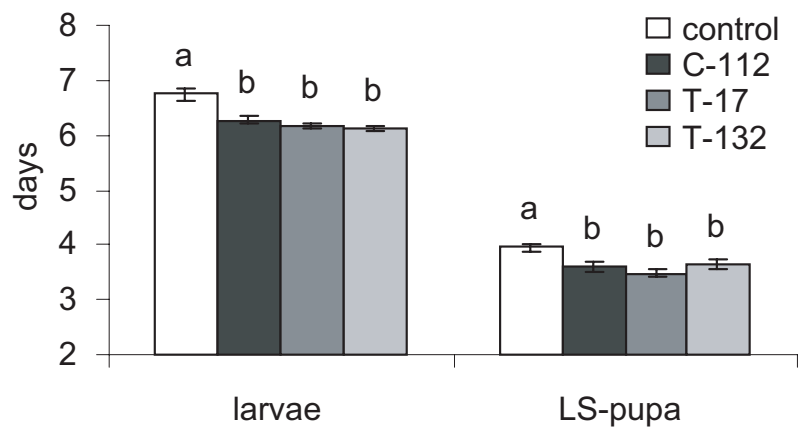

Figure 5. Mean developmental time ( \pm s.e.) until LS and from LS to pupal stage when feeding on the different diets. Different letters indicate significant differences in developmental times $(\mathrm{p}<0.05)$.

does not pose a hazard to honey bee larvae when presented in a worst-case scenario, where exposure levels were high and the larvae likely to be at a vulnerable early stage of development.

The dose of $1.5 \%$ pollen (equivalent to $4 \%$ in fresh pollen) was chosen to make sure that larvae were fed as much pollen as possible, and therefore also as much PSL that possibly could be received through the pollen in the food, in order to create a worst case scenario. The amount of pollen that could be mixed into the food without negative impact on larval development was lower in this study than the levels previously recorded for pollen from samples of mixed plant species found in samples of brood food taken from larval cells in outdoor hives (Malone et al., 2002). However, a previous test with fresh oilseed rape pollen found lethal pollen concentrations at 5\% (H. Brødsgaard, pers. comm.), similar to the critical level found here, which was $4 \%$ when recalculating dry weight to fresh weight. The concentration of PSL was somewhat higher in T-17, but the total protein 
concentration was somewhat lower in this line compared to line T-132, resulting in the same PSL concentration in the transgenic diets.

There was a positive effect of pollen in general, as larval weights increased and larval development became faster on all pollen-containing diets. The positive effects of pollen were probably a result of the additional protein the larvae received through the pollen (Roulston and Cane, 2002). Pollen is hard to digest due to the indigestible cell wall and in both larvae and adults the grains are digested in the midgut where the pollen content is extracted through pollen germination pores or by rupture of the cell wall by osmotic shock (Winston, 1987). There was no doubt that the larvae ate the pollen along with the royal jelly and sugar solution, because the accumulation of pollen material in the ventriculus could be seen by the naked eye in larvae fed the pollen-containing diets. Also, the faeces of those larvae had a darker yellow color. In the present study, the total soluble protein content was $7.6 \%$ for the dry pollen, which corresponds to $2.9 \%$ protein in fresh pollen. Protein content in freshly frozen anthers of the tested plant material was $6.4 \%$, which corresponds to $16.7 \%$ protein (w/w) when dried (Lehrman, unpublished). The lectin content in the food used in the experiments would then be $0.0006 \%$ less than a diet containing frozen anthers.

The rather high mortality in the present study compared to others (Aupinel et al., 2005; Genersch et al., 2005; Peng et al., 1992) may have been due to physical damage when the larvae were moved between wells. However, the effect of the treatments should not be influenced by a somewhat increased control larval mortality. Possibly, the handling problem could have been avoided by following the technique developed by Aupinel et al. (2005), where the larvae are not disturbed during their development.

Compared to adult honey bees, the larvae are in a nochoice situation. They have to feed on what is offered, whereas adults can avoid food of inferior quality. Larvae also need a more complex diet than the adults, and this could make them more sensitive to changes in food composition. Under natural conditions, larvae would not be fed pollen during the first days of their lives. But, as discussed in the introduction, they may still receive PSL through the royal jelly produced by the nursing bees. With a maximum of $4 \%$ pollen (fresh) containing $0.7 \%$ PSL (Lehrman et al., 2007) of total soluble protein, the actual amount of PSL in the food would, even if all pollen collected by the worker bees came from the transgenic plants, be quite low $(0.0018 \%)$. Although the level of PSL in the diet was slightly lower than it would have been if fresh/frozen pollen was used, all larval stages were exposed to PSL in pollen, which would not have been the case under natural conditions.
In conclusion, dried transgenic pollen, expressing up to $1.2 \%$ PSL (of total soluble protein) showed no effect on bee larval survival, weight, or development time compared to non-transgenic pollen when mixed in the diet at $1.5 \%(\mathrm{w} / \mathrm{w})$. The addition of pollen (transgenic and non-transgenic) to the diet increased larval weight and reduced developmental time. The results suggest that at the levels presented here, transgenic PSL poses no hazard to honey bee larvae.

\section{MATERIALS AND METHODS}

\section{Plant materials}

Three plant lines, two transgenic (designated T-17 and T-132) and one control (designated C-112), of oilseed rape (B. napus cv. Westar) were tested. All three lines originated from cotyledon cells transformed with the pea lectin gene under control of the anther specific promoter of the Sta-44-4 gene from B. napus (Hong et al., 1997; Melander et al., 2003). The control line came from a selfed $\mathrm{T}_{0}$ plant with offspring segregated for transgenicity in $\mathrm{T}_{1}$ (and consequently did not express any pea lectin). The plants used in the experiments were 3rd generation doubled-haploid plants produced from microspores of $T_{3}$-plants. The plant lines were selected to match each other in phenology and seed yield (Åhman et al., 2006). The plants for pollen harvest were grown in $11 \mathrm{~cm}$ diameter pots containing Hammenhög's potting soil, additionally fertilized with Osmocote (Econova) and micronutrients Multifritt (Hammenhögs). The cultures were kept in cooled greenhouse chambers $(20 \pm$ $2{ }^{\circ} \mathrm{C}$, natural light) and were treated against thrips and aphids with the biological control agents Thripex-plus (Amblyseius cucumeris (Oud.)) and Aphipar (Aphidius colemani (Vier.) Econova Predator AB).

Flowers were collected from several plants from each of the three plant lines during the summer of 2005. The flowers were dried for $48 \mathrm{~h}$ at $38{ }^{\circ} \mathrm{C}$ and stored at $13{ }^{\circ} \mathrm{C}$ and $45-50 \%$ humidity. The following spring, pollen was sieved from the flowers through metal mesh $(0.34 \times 0.34 \mathrm{~mm})$. Additionally, three samples of fresh pollen were weighed, dried and weighed again in order to determine the water loss in the dried pollen.

\section{Western analysis of PSL in dried pollen}

Total protein was extracted from the dried pollen using T-PER Tissue Protein Extraction reagent (Pierce, Rockford, IL, USA) according to the protocol with the addition of $1 \%$ proteinase inhibitor (Roche diagnostics, Mannheim, Germany). The soluble protein was quantified with Bio-Rad Protein Assay (Bio-Rad Laboratories, 
Hercules, CA, USA) using Bovine serum albumin (BSA) as standard. Proteins were separated on NuPAGE Bis-Tris gel (Invitrogen, Carlsbad, CA, USA) along with purified PSL (Sigma-Aldrich, Stockholm, Sweden) and blotted on a nitrocellulose membrane, incubated with rabbit primary antibody against PSL (described in Melander et al., 2003), dilution 1:10 000, and secondary antibody, ECL ${ }^{\mathrm{TM}}$ Anti-rabbit IgG (GE Healthcare, Buckinghamshire, UK) (1:20 000). The bands were visualized using LAS-3000 2.0 (Fuji Photo Film Co. Ltd) program and the band strength was quantified using Quantity One Basic (BioRad) software program.

\section{Honey bee larvae}

Worker larvae were obtained from honey bee (A. mellifera) colonies kept at the Ultuna apiary close to Uppsala, Sweden. The larvae were reared in vitro in 24-well tissue culture plates, according to Peng et al. (1992) modified by Genersch et al. (2005), in an incubator at $35^{\circ} \mathrm{C}$ with a relative humidity of $96 \%$. The larvae were collected up to $24 \mathrm{~h}$ after hatching from brood combs using a Chinese grafting tool (Graze Bienenzuchtgeräte, Germany) and transferred to the surface of the experimental food. The assays started (day 0) with 10 larvae/well containing approximately $300 \mu \mathrm{L}$ food (one well per plate in feeding assay 1, and two wells per plate in assay 2). Due to larval growth, the number of larvae per well was then reduced to five, three, two and one at the second, third, and fourth day, respectively. From day five the amount of food was changed to $200 \mu \mathrm{L}$ per well.

\section{Feeding assay 1; pollen concentration}

In order to determine how much dried pollen could be added to the food without severely affecting the survival of the larvae, four different levels of pollen from the nonlectin-expressing plant line C-112 (Tab. 2) were mixed in the basic food consisting of $66 \%$ (w/v) royal jelly (Stakich), 3\% glucose and 3\% fructose in sterile distilled water. In order to obtain the same viscosity in the different diets, additional water had to be added (see Tab. 2). A total of 150 honey bee larvae were tested (3 replicates of 10 on each diet - four with pollen and one without) as described above. New food was prepared at least every third day and stored at $8{ }^{\circ} \mathrm{C}$. The food was heated to approximately $30^{\circ} \mathrm{C}$ before being fed to the larvae. Surviving larvae were counted every day until day five when the test ended.

The number of survivors per replicate in the treatments was normally distributed. Thus, a one way ANOVA (general linear model) was performed for day five. The results indicated that the highest amount of
Table 2. Composition of the diets with different pollen concentrations used in feeding assay 1. Pollen was from the non-lectinexpressing plant line C-112.

\begin{tabular}{lccc}
\hline \hline & $\begin{array}{c}\text { Basic } \\
\text { diet }\end{array}$ & Water & $\begin{array}{c}\text { Dried } \\
\text { pollen }\end{array}$ \\
\hline 0 & $10 \mathrm{~g}$ & - & - \\
$1 \%$ & $9.7 \mathrm{~g}$ & $200 \mu \mathrm{L}$ & $100 \mathrm{mg}$ \\
$2 \%$ & $9.4 \mathrm{~g}$ & $400 \mu \mathrm{L}$ & $200 \mathrm{mg}$ \\
$3 \%$ & $9.1 \mathrm{~g}$ & $600 \mu \mathrm{L}$ & $300 \mathrm{mg}$ \\
$4 \%$ & $8.8 \mathrm{~g}$ & $800 \mu \mathrm{L}$ & $400 \mathrm{mg}$ \\
\hline
\end{tabular}

pollen that left the larvae unaffected was somewhere between 1 and $2 \%$ (Fig. 2). Thus, a level of $1.5 \%$ pollen in the larval food was chosen for the lectin experiments. Number of pollen grains in the food at the $1.5 \%$ level was counted using a $0.1 \mathrm{~mm}$ Bürker counting chamber.

\section{Feeding assay 2; transgenic pollen}

Four diets were compared: one with basic food only, and three with dried pollen from control plant line C-112, and the transgenic lines T-17 and T- 132. The pollen was mixed with the basic food at a $1.5 \%$ pollen concentration. For a batch of $10 \mathrm{~g}$ pollen-containing food, $9.55 \mathrm{~g}$ of basic food was mixed with $300 \mu \mathrm{L}$ of water and $150 \mathrm{mg}$ dried pollen. A total of 400 larvae were tested (10 replicates of 10 on each diet). The assay was performed in the same way as described in Feeding assay 1, but in this test the larvae were fed until they became passive and started to excrete faeces, the LS-stage (Rembold et al., 1980). At this stage the larvae were gently wiped with a paper towel, weighed and moved to a new well lined with paper towels. The paper was changed every day until excretion stopped. The plates were kept in a sealed plastic box containing a steel mesh leaving a $2.5 \mathrm{~cm}$ space down to the bottom, which was covered with approximately $1 \mathrm{~cm}$ of $0.2 \mathrm{M} \mathrm{H}_{2} \mathrm{SO}_{4}$ in order to prevent fungal growth. Survival rate until the LS stage was monitored, and developmental time was calculated for the larval, LS and pupal stages. Normal distribution and homogeneity of variances for the number of surviving bees were checked by graphical inspection of residuals for each day of the larval, LS and pupal stage. To determine if there were differences between the diets a repeated measures analysis (procedure mixed, compound symmetry as covariance structure) was performed. Because it is difficult to determine if a larva is dead or alive when entering the LS-stage, the repeated measures ANOVA was only calculated for the first six days. Survivorship in the LS and pupal stage were compared in a one-way ANOVA (glm). Data for larval weights (when entering LS-stage) 
and development time for larval, LS and pupal stage were not normally distributed. Therefore the non-parametric Kruskal-Wallis test was performed. Correlation between larval weight and development time was explored using Spearman correlation coefficients. All statistical analyses were performed using SAS 9.1 (Cary, NC, USA) software.

\section{ACKNOWLEDGEMENTS}

The author thanks Ingemar Fries, Anders Lindström and Eva Forsgren for help with rearing of honey bee larvae and fruitful discussions. I am grateful to Per Hydbring for help with the western blot. I also wish to thank Henrik Brødsgaard for helpful suggestion regarding the methods. This work was funded by the Swedish Research Council for Environment, Agricultural Sciences and Spatial Planning (FORMAS).

Received March 29, 2007; accepted July 24, 2007.

\section{REFERENCES}

Åhman I, Melander M (2003) Potato proteins, and other plant proteins, as potential transgenic resistance factors to pollen beetles in oilseed rape. Ann. Appl. Biol. 143: 253-260

Åhman IM, Kazachkova NI, Kamnert IM, Hagberg PA, Dayteg CI, Eklund GM, Meijer LJO, Ekbom B (2006) Characterisation of transgenic oilseed rape expressing pea lectin in anthers for improved resistance to pollen beetle. Euphytica 151: 321-330

Andersson G, Berg G, Djurberg A, Ewaldz T, Gustafsson G, Lerenius C, Mellqvist E, Sandström M, Waern $\mathbf{P}$ (2006) Bekämpningsrekommendationer svampar och insekter. Swedish Board of Agriculture

Arpaia S (1996) Ecological impact of Bt-transgenic plants: 1. Assessing possible effects of CryIIIB toxin on honey bee (Apis mellifera L.) colonies. J. Genet. Breed. 50: 315-319

Aupinel P, Fortini D, Dufour H, Tasei J-N, Michaud B, Odoux J-F, Pham-Delègue M-H (2005) Improvement of artificial feeding in a standard in vitro method for rearing Apis mellifera larvae. Bull. Insectol. 58: 107-111

Babendreier D, Kalberer N, Romeis J, Fluri P, Mulligan E, Bigler F (2005) Influence of Bt-transgenic pollen, Bt-toxin and protease inhibitor (SBTI) ingestion on development of the hypopharyngeal glands in honeybees. Apidologie 36: 585594

Baker HG, Baker I (1986) The occurrence and significance of amino acids in floral nectar. Plant. Syst. Evol. 151: 175-186

Belzunces LP, Lenfant C, Di Pasquale S, Colin M-E (1994) In vivo and in vitro effects of weat germ agglutinin and
Bowman-Birk soybean trypsin inhibitor, two potential transgene products, on midgut esterase and protease activities from Apis mellifera. Comp. Biochem. Physiol. B Comp. Biochem. 109: 63-69

Brødsgaard HF, Brødsgaard CJ, Hansen H, Lövei GL (2003) Environmental risk assessment of transgene products using honey bee (Apis mellifera) larvae. Apidologie 34: 139

Burgess EPJ, Malone LA, Christeller JT (1996) Effects of two proteinase inhibitors on the digestive enzymes and survival of honey bees (Apis mellifera). J. Insect. Physiol. 42: 823-828

Crailsheim K (1990) The protein balance of the honey bee worker. Apidologie 21: 417-429

Crailsheim K, Schneider LHW, Hrassnigg N, Bühlmann G, Brosch U, Gmeinbauer R, Schöffmann B (1992) Pollen consumption and utilization in worker honeybees (Apis mellifera carnica): dependence on individual age and function. $J$. Insect. Physiol. 38: 409-419

Davidson EW (1970) Ultrastructure of peritrophic membrane development in larvae of the worker honey bee (Apis mellifera). J. Invertebr. Pathol. 15: 451-454

Derron JO, LeClech E, Bezençon N, Goy G (2004) Résistance des méligèthes du colza aux pyréthrinoïdes dans le bassin lémanique. Revue Suisse Agric. 36: 237-242

Eisemann CH, Donaldson RA, Pearson RD, Cadogan LC, Vuocolo T, Tellam RL (1994) Larvicidal activity of lectin on Lucilia cuprina: mechanism of action. Entomol. Exp. Appl. 72: $1-10$

Ekbom B, Kuusk A-K (2001) Rapsabaggar och resistens mot pyretroider. Vaxtskyddsnotiser 65: 39-42

Elden TC (2000) Effects of proteinase inhibitors and plant lectins on the adult alfalfa weevil (Coleoptera: Curculionidae). J. Entomol. Sci. 35: 62-69

Gatehouse A, Gatehouse J (1996) Effects of lectins on insects. In: Bardocz S, Gelencser E, Pusztai A, eds, Effects of Antinutrients on the Nutritional Value of Legume Diets. Luxembourg: COST 98, European Commission

Genersch E, Ashiralieva A, Fries I (2005) Strain- and genotype-specific differences in virulence of Paenibacillus larvae subsp. larvae, a bacterial pathogen causing American foulbrood disease in honeybees. Appl. Environ. Microbiol. 71: 7551-7555

Gupta G, Birah A, Rani S (2005) Effect of plant lectins on growth and development of American bollworm (Helicoverpa armigera). Indian J. Agric. Sci. 75: 207-212

Hanley AV, Huang ZY, Pett WL (2003) Effects of dietary transgenic Bt corn pollen on larvae of Apis mellifera and Galleria mellonella. J. Apic. Res. 42: 77-81

Hansen LM (2003) Insecticide-resistant pollen beetles (Meligethes aeneus) found in Danish oilseed rape (Brassica napus) fields. Pest. Manag. Sci. 59: 1057-1059

Harper SM, Crenshaw RW, Mullins MA, Privalle LS (1995) Lectin binding to insect brushborder membranes. J. Econ. Entomol. 88: 1197-1202 
Harper MS, Hopkins TL, Czapla TH (1998) Effect of weat germ agglutinin on formation and structure of the peritrophic membrane in European corn borer (Ostrinia nubilalis) larvae. Tissue Cell 30: 166-176

Haydak MH (1943) Larval food and development. J. Econ. Entomol. 36: 778-792

Haydak MH (1963) Influence of storage on the nutritive value of pollen for brood rearing by honeybees. J. Apic. Res. 2: 105107

Hong HP, Gerster JL, Datla RSS, Albani D, Scoles G, Keller W, Robert LS (1997) The promoter of a Brassica napus polygalacturonase gene directs pollen expression of $\hat{\mathrm{I}}^{2}$-glucuronidase in transgenic Brassica plants. Plant. Cell Rep. 16: 373-378

Klein A-M, Vaissière BE, Cane JH, Steffan-Dewenter I, Cunningham SA, Kremen C, Tscharntke T (2007) Importance of pollinators in changing landscapes for world crops. Proc. R. Soc. B 274: 303-313

Lehrman A, Åhman I, Ekbom B (2007) Influence of pea lectin expressed transgenically in oilseed rape (Brassica napus) on adult pollen beetle (Meligethes aeneus). J. Appl. Entomol. 131: $319-325$

Liu B, Xu C, Yan F, Gong R (2005) The impacts of the pollen of insect-resistant transgenic cotton on honeybees. Biodivers. Conserv. 14: 3487-3496

Malone LA, Tregidga EL, Todd JH, Burgess EPJ, Philip BA, Markwick NP, Poulton J, Christeller JT, Lester MT, Gatehouse HS (2002) Effects of ingestion of a biotin-binding protein on adult and larval honey bees. Apidologie 33: 447458

Malone LA, Todd JH, Burgess EPJ, Christeller JT (2004) Development of hypopharyngeal glands in adult honey bees fed with a Bt toxic, a biotin-binding protein and a protease inhibitor. Apidologie 35: 655-664

Melander M, Åhman I, Kamnert I, Strömdahl A-C (2003) Pea lectin expressed transgenically in oilseed rape reduces growth rate of pollen beetle larvae. Transgenic Res. 12: $555-567$

Murdock LL, Shade RE (2002) Lectins and protease inhibitors as plant defenses against insects. J. Agric. Food Chem. 50: 6605-6611
Nilsson C (1987) Yield losses in summer rape caused by pollen beetles (Meligethes spp.). Swedish J. Agri. Res. 17: 105-111

O'Callaghan M, Glare TR, Burgess EPJ, Malone LA (2005) Effects of plants genetically modified for insect resistance on nontarget organisms. Annu. Rev. Entomol. 50: 271-292

Peng Y-SC, Mussen E, Fong A, Montague MA, Tyler T (1992) Effects of chlortetracycline on honey bee worker larvae reared in vitro. J. Invertebr. Pathol. 60: 127-133

Peumans WJ, Van Damme EJM (1995) Lectins as plant defense proteins. Plant. Physiol. 109: 347-352

Peumans WJ , Smeets K, Van Nerum K, Van Leuven F, Van Damme EJM (1997) Lectin and alliinase are the predominant proteins in nectar from leek (Allium porrum L.) flowers. Planta 201: 298-302

Powell KS, Spence J, Bharathi M, Gatehouse JA, Gatehouse AMR (1998) Immunohistochemical and developmental studies to elucidate the mechanism of action of the snowdrop lectin on the rice brown planthopper, Nilaparvata lugens (Stal). J. Insect. Physiol. 44: 529-539

Prasthofer T, Phillips SR, Suddath FL, Engler JA (1989) Design, expression, and crystallization of recombinant lectin from garden pea (Pisum sativum). J. Biol. Chem. 264: 67936796

Rembold H, Kremer J-P, Ulrich GM (1980) Characterization of postembryonic developmental stages of the female castes of the honey bee, Apis mellifera L. Apidologie 11: 29-38

Roulston TaH, Cane JH (2002) The effect of pollen protein concentration on body size in the sweat bee Lasioglossum zephyrum (Hymenoptera: Apiformes). Evol. Ecol. 16: 49-65

Sagili RR, Pankiw T, Zhu-Salzman K (2005) Effects of soybean trypsin inhibitor on hypopharyngeal gland protein content, total midgut protease activity and survival of the honey bee (Apis mellifera L.). J. Insect. Physiol. 51: 953-957

Sétamou M, Bernal JS, Legaspi JC, Mirkov TE, Legaspi Jr BC (2002) Evaluation of lectin-expressing transgenic sugarcane against stalkborers (Lepidoptera: Pyralidae): Effects on life history parameters. J. Econ. Entomol. 95: 469-477

Winston ML (1987) The biology of the honey bee. Cambridge, Massachusetts, Harvard University Press 